Meta

Journal des traducteurs

Translators' Journal

\title{
Translation in the European Parliament: The Study of the Ideational Function in Technical Texts (EN/FR/ES)
}

\section{María Azahara Veroz}

Volume 62, numéro 1, avril 2017

URI : https://id.erudit.org/iderudit/1040465ar

DOI : https://doi.org/10.7202/1040465ar

Aller au sommaire du numéro

Éditeur(s)

Les Presses de l’Université de Montréal

ISSN

0026-0452 (imprimé)

1492-1421 (numérique)

Découvrir la revue

Citer cet article

Veroz, M. A. (2017). Translation in the European Parliament: The Study of the Ideational Function in Technical Texts (EN/FR/ES). Meta, 62(1), 19-44. https://doi.org/10.7202/1040465ar
Résumé de l'article

Dans cet article, nous abordons l'étude des textes techniques du Parlement européen en trois langues, anglais-espagnol-français, en nous concentrant sur leurs caractéristiques discursives et, plus concrètement, sur la manière dont la fonction idéationnelle est exprimée. Nous avons suivi la méthodologie proposée par la Linguistique systémique fonctionnelle après avoir compilé un corpus parallèle trilingue composé de textes techniques téléchargés depuis le site du Parlement européen (PE).

Conformément à l'analyse proposée, nous avons trouvé que ces textes se caractérisent par une prédominance de processus matériels, en particulier les actions liées au monde juridique, administratif et économique comme adopter approuver, modifier, créer, transmettre, publier, établir et signer, avec leurs équivalents respectifs en espagnol et en anglais. Bien qu'il existe certains processus (mentaux (cognition) et verbaux) qui pourraient avoir une nature mixte, puis que nous avons observé que leurs équivalents sont interchangeables entre eux (mental>verbal, verbal>mental, matériel>mental) dans certains cas, dans les différentes versions linguistiques étudiées.

En ce qui concerne les participants (agent, affected, recipient, beneficiary et sayer), la plupart d'entre eux sont des institutions et des actes / documents, alors que ces actions sont généralement effectuées par des personnes. Nous concluons que la connaissance de ces caractéristiques pourrait être utile pour les traducteurs de l'UE et doit être utilisée dans la formation des futurs traducteurs comme un guide dans le processus de traduction.
Ce document est protégé par la loi sur le droit d'auteur. L'utilisation des services d'Érudit (y compris la reproduction) est assujettie à sa politique d'utilisation que vous pouvez consulter en ligne.

https://apropos.erudit.org/fr/usagers/politique-dutilisation/ 


\title{
Translation in the European Parliament: The Study of the Ideational Function in Technical Texts (EN/FR/ES)
}

\author{
MARÍA AZAHARA VEROZ \\ Universidad de Córdoba. Córdoba, España \\ z92vegom@uco.es
}

\section{RÉSUMÉ}

Dans cet article, nous abordons l'étude des textes techniques du Parlement européen en trois langues, anglais-espagnol-français, en nous concentrant sur leurs caractéristiques discursives et, plus concrètement, sur la manière dont la fonction idéationnelle est exprimée. Nous avons suivi la méthodologie proposée par la Linguistique systémique fonctionnelle après avoir compilé un corpus parallèle trilingue composé de textes techniques téléchargés depuis le site du Parlement européen (PE).

Conformément à l'analyse proposée, nous avons trouvé que ces textes se caractérisent par une prédominance de processus matériels, en particulier les actions liées au monde juridique, administratif et économique comme adopter, approuver, modifier, créer, transmettre, publier, établir et signer, avec leurs équivalents respectifs en espagnol et en anglais. Bien qu'il existe certains processus (mentaux (cognition) et verbaux) qui pourraient avoir une nature mixte, puis que nous avons observé que leurs équivalents sont interchangeables entre eux (mental>verbal, verbal>mental, matériel>mental) dans certains cas, dans les différentes versions linguistiques étudiées.

En ce qui concerne les participants (agent, affected, recipient, beneficiary et sayer), la plupart d'entre eux sont des institutions et des actes / documents, alors que ces actions sont généralement effectuées par des personnes. Nous concluons que la connaissance de ces caractéristiques pourrait être utile pour les traducteurs de l'UE et doit être utilisée dans la formation des futurs traducteurs comme un guide dans le processus de traduction.

\footnotetext{
ABSTRACT

In this paper we tackle the study of European Parliament technical texts in three languages, namely English-Spanish-French, focusing on their discursive features and, more concretely, on the way in which the ideational function is expressed in them. To achieve this end, we have followed the frame of the Systemic Functional Grammar compiling a trilingual parallel corpus composed of technical texts downloaded from the European Parliament (EP) Website.

In accordance with the analysis proposed it is proved that these texts are characterized by a predominance of material processes, in particular, actions linked to the legal, administrative and economic world like adopt, approve, modify, create, transmit, publish, establish and sign, with their respective equivalents in Spanish and French. Although there are certain processes - mental (cognition) and verbal ones - that could have a mixed nature, as we have observed that equivalents are exchanged with each other in the different linguistic versions studied.

Regarding the participants (agent, affected, recipient, beneficiary and sayer), most of them are institutions and acts/documents, when these participants in these processes are usually humans. We conclude that knowledge of these features could be useful for EU translators and should be used in the training of future translators as a guide in the translation process.
} 


\section{RESUMEN}

En este artículo estudiamos los textos técnicos del Parlamento Europeo (PE) en tres lenguas: inglés, español y francés; en concreto, el estudio de sus características discursivas y cómo la función ideacional se hace presente en ellos. Para realizarlo se ha seguido la metodología propuesta por la Lingüística Sistémica Funcional aplicada a corpus trilingüe paralelo compuesto por textos técnicos descargados del sitio web del Parlamento Europeo.

Según el análisis propuesto, se ha demostrado que estos textos se caracterizan por el predominio de procesos materiales, en particular, de acciones ligadas al ámbito jurídico, administrativo y económico como adoptar, aprobar, modificar, creer, transmitir, publicar, establecer y firmar, con sus equivalentes en inglés y francés. No obstante, hemos observado que existen una serie de procesos que podrían considerarse de naturaleza mixta (mentales (cognitivos) y verbales) cuyos equivalentes entre las lenguas estudiadas en ocasiones son intercambiables.

En lo que se refiere a los participantes (agent, affected, recipient, beneficiary y sayer), se podría decir que son en su mayoría instituciones y documentos o actos jurídicos los que realizan acciones que normalmente llevan a cabo humanos. Consideramos que los resultados derivados de este estudio podrían ser de gran utilidad para los traductores de la Unión Europea y que deberían tenerse en cuenta en la formación de futuros traductores.

\section{MOTS-CLÉS/ KEYWORDS/PALABRAS CLAVE}

traduction institutionnelle, parlement européen, textes techniques, linguistique systémique fonctionnelle, corpus parallèle trilingue

institutional translation, European Parliament, technical texts, systemic functional grammar, trilingual parallel corpus

traducción institucional, parlamento Europeo, textos técnicos, lingüística sistémica funcional, corpus trilingüe paralelo

\section{Introduction}

Nowadays, most studies dealing with EU translation focus on legal texts, understood as normative texts which establish rights and duties for all citizens in the European Union, either directly, as regulations, or indirectly, as directives. These texts may also address specific recipients, in the form of decisions or recommendations. However, there are no studies on technical texts understood as texts which contain data, opinions, judgments, analyses and reports, providing the legal context found in regulations, directives, decisions and recommendations. These texts include the communicative exchanges among the EU administration, citizens and enterprises in the European Union. This is the reason why we consider these texts of vital importance, since most of the translation activities carried out in the EU institutions centre around them (Garrido and Navarrete 2004: 162-163).

Therefore, our initial hypothesis can be formulated as follows: "EP technical texts have common linguistic features in their English, French and Spanish versions."

In this paper we tackle the study of European Parliament technical texts (Garrido and Navarrete 2004) in three languages, namely English-Spanish-French, focusing on their discursive features and, more concretely, on the way in which the ideational function is expressed in them. To achieve this end, we shall follow the frame of the Systemic Functional Grammar (Halliday and Matthiessen 2004). We have compiled 
a trilingual parallel corpus (English, French and Spanish) composed of technical texts downloaded from the European Parliament (EP) Register of Documents from the EP Web site. ${ }^{1}$

We attempt to study and discuss UE texts concerned with political, legal, economic, technical and scientific areas. Our main goals are:

1. To identify the linguistic features characteristic of the technical texts produced by the European Parliament from the point of view of the ideational function.

2. To determine the most appropriate translation methods to be applied in this particular case.

We must make clear that this study is part of a larger research where a full systemic functional analysis is made, i.e., including the interpersonal and textual function analysis.

In EU texts translation, from a theoretical standpoint we rely on the notion of equivalence to the original; this notion has been a long-debated issue in translation studies and has been approached by several authors (Reiss and Vermeer 1996; Nord 1991, 1997; Toury 1997). Another problem raised by translation scholars has been how to get the original text and its translation to be the same text when all the factors involved in the process are, by definition, different (Catford 1977; Hatim and Mason 1995; Neubert and Shreve 1992). Furthermore, EU texts translation poses another problem apart from the 'equivalence' linguistic problem, namely, that the equivalence must also be 'legal' in principle. Therefore, the translation of EU texts requires an identical formulation in each of the official languages (Gómez González-Jover 2002).

Thus, we argue that legal equivalence is what differentiates EU texts from texts produced by other international organizations, since there is apparently neither source text nor target text in the EU texts and the translator has to produce a second source text with equal legal validity (Pym 1999). In sum, translators must reconcile unity and diversity in performing their task, while taking into account the cultural differences without undermining their shared identity features.

For all the above reasons, EU translation is a highly regulated activity, as all the divisions have to produce equivalent legal texts which look as if they were written by a single person; in other words, the translation of official EU texts involves an identical formulation in each of the official languages (Gómez González-Jover 2002). Thus, as we mentioned at the beginning of this paper, Garrido and Navarrete (2004) argue the following about institutional translation and the role of the institutional translator:

There is no single type of 'institutional' texts, but many and of varied character: from the project that will eventually become a regulation or a recommendation for the Member States, to an informative brochure for the citizens; the interventions by MEPs, the judgments of the Court of Justice, the letters sent by citizens or referred to these by institutions, the notices of competitions, internal memos, newsletters and Internet publishing and dozens of other texts of a wide variety of types.

Garrido and Navarrete (2004) provide the following classification:

a) Dispositive texts, which are regulatory texts, establishing rights and duties for all the citizens of the European Union. The Directives, Regulations, Decisions and Recommendations, and the judgments handed down by the Court of Justice of the European Union (ECJ) are included within these texts. Except for the Decisions and judgments, which have a special linguistic regime, the rest of the cited texts 
must be translated into every EU official language and they are considered original texts in each language, i.e. they are not considered translations according to the principle of equality and non-discrimination.

b) Technical and administrative communication texts. These texts serve as a basis for the elaboration of regulatory texts: reports, amendments and opinions. These texts do not have legal relevance, they are informative and do not create either rights or obligations. An example could be a report on the Spanish economic situation or an opinion on privacy of personal data on the Internet elaborated by a Parliamentary Committee. Administrative communications, meanwhile, are epistolary exchanges between the EU administration and EU citizens; in some cases, they may generate duties to citizens and countries as they could incur an administrative infringement if they do not act as the document suggests. However, the EP written questions between MEPs and the Commission could be considered as administrative communications, as they are epistolary exchanges, although their main function is the parliamentary control of the Commission, and they do not generate any legal right or obligation.

c) Procedural Texts are texts derived from the internal communications between administration and the civil service.

To these we may add informative texts, which would range from information websites of the European Union to informative brochures.

This initial classification has helped us contextualise the texts we have analysed, their nature, origin and destination which differ in many respects from the speakerrecipient point of view. In this particular case, we should highlight the role of the translator and the translation problems s/he may find, for example, concerning the doubtful consistence of the original texts (Koskinen 2001), which are often the result of a series of modifications, or even translations, made by various authors that are often expressed in a language that is not their own (Wagner 2002).

For this reason, we have reviewed two methodologies in order to carry out our research:

a) On the one hand, the main exponents of the methodology used in the analysis of our corpus following the methods exposed by Corpus Linguistics, which has been so useful for our research in order to compile, choose, process and analyse our corpus of texts.

b) On the other, the LSF (Halliday and Hasan 1976, 1978, Halliday and Matthiessen 2004; Downing 2006), the core works guiding our research.

Then, our results and conclusions will be presented and discussed.

\section{Methodological framework}

\subsection{Corpus design according to Corpus Linguistics Methodology}

In this section, we will focus on the basic criteria followed in order to compile our corpus. The written literature on the criteria to be taken into account when designing a corpus is extensive, understanding that the corpus design must be prior to the creation of the corpus: "theoretical research should always precede the initial corpus design and actual compilation of text" (Biber 1993: 256). Therefore, we must be clear when designing our corpus premises. We also must keep in mind that the quality of the corpus will directly affect the results of our research: 
The beginning of any corpus study is the creation of the corpus itself. The decisions that are taken about what is to be in the corpus, and how the selection is to be organized, control almost everything that happens subsequently. The results are only as good as the corpus. (Sinclair 1991: 13)

Sinclair, in EAGLES (1996b: 4) defines the minimum criteria for a set of texts to be considered a corpus (quantity, quality, simplicity and documentation):

- The corpus should be as large as could possibly be envisaged with the technology of the time $[\ldots]$

- It should include samples from a broad range of material in order to attain some sort of representativeness.

- There should be an intermediate classification into genres between the corpus in total and the individual samples.

- The samples should be of an even size.

- The corpus as a whole should have a declared provenance.

(Eagles 1996b: 4)

In recent years, the first two recommendations have raised controversy regarding quality and quantity. Some scientists have given more importance to the fact that the corpus was representative and balanced, while some others have given more importance to its size (Pérez Hernández 2002). In our opinion, the size of a corpus will depend on the purpose of the research, although we should keep in mind that the corpus must be representative of the language or of the language fraction we wish to study.

To carry out this study we have followed the recommendations made by Bowker and Pearson (2002), establishing seven design criteria:

a) size of the corpus,

b) type of texts,

c) number of texts,

d) channel,

e) author,

f) language/s,

g) date.

When designing the corpus, we have chosen a mainly qualitative research method; therefore, we have decided to take a sample of the entire corpus available in the Register of Documents of the European Parliament from 2010-2013, as, in our case, it would be difficult to make a qualitative analysis of the corpus available in this Website. For this reason, we must make clear that our figures, although quantified, will only be representative of the compiled sample.

TABLE 1

Corpus available/corpus under analysis

\begin{tabular}{|l|l|}
\hline Corpus available $2010-2013^{2}$ & Corpus under analysis \\
\hline 996.997 documents & 60 texts \\
\hline
\end{tabular}

We have selected texts that fulfilled the following criteria: a) texts that have been translated into or from the languages of this study (English, French and Spanish); b) texts that are frequently translated, as one of the future aims of this study might be the establishment of a translation method for EU translators. 
To obtain this information, we contacted the DG TRAD Multilingualism and External Relations in May 2012, for the data indicated below, and then in December 2013 to see if these figures had been modified. We were interested in:

- Volume translation figures, i.e., documents translated, number of pages delivered in EU languages to translate and all types of translated documents.

- Pages of origin submitted for translation.

- A report on the volume of documents produced by the European Parliament in Spanish (originals and translations), including languages (source and translation) and type of documents.

According to this information, we decided to select those subgenres that are within the most translated ten types of documents according to these criteria. Thus, the subgenres we have finally analysed are:

- amendments (AD),

- reports $(\mathrm{AM})$

- opinions (RR),

- written questions (QE).

Therefore, the final design of our corpus was the following:

TABLE 2

Final corpus design based on Bowker and Pearson's (2004: 54) model

\begin{tabular}{|l|l|}
\hline Size & 46 954 tokens aprox \\
\hline Number of texts & 60 \\
\hline Channel & Written \\
\hline Subject & Any subject covered in the EP \\
\hline Subgenre & Amendment, reports, opinions and written questions. \\
\hline Author & MEPs, European Parliament \\
\hline Language/s & English, French and Spanish \\
\hline Data & $2010-2013$ \\
\hline
\end{tabular}

\subsection{Systemic Functional Grammar (SFG) Methodology}

We usually look for the defining characteristics of texts in their linguistic structure (whether oral or written). Accordingly, to know the defining characteristics of technical and administrative communication texts, we must know the structure of these texts. This study has been performed from the context properties, i.e., the European Union, as technical and administrative communication texts are produced within the European Parliament, an institution representing the citizens of the EU, whose main actors are the MEPs, i.e., politicians whose language is governed by the contextual and cultural situation around them. Therefore, since the SFG is the linguistic approach that relies more on the context, we consider that this analysis should be performed from this methodological framework.

The functionalists focus all their attention on showing how the organization of language is related to its use, i.e., language and context are directly related. Thus, Halliday (1978: 142) explains that: "The particular form taken by the grammatical system of language is closely related to the social and personal needs that language is required to serve." 
Most experts doing research on the functions of language agree that there are two principal functions: the experiential function, which has the mission of interpreting the experience of transmitting knowledge, and the interpersonal one, whose role is to connect us to other people. In the field of Euro-parliamentary texts, the first would correspond to the acquis communautaire and the second to the relationship between the members of the European Parliament (either Euro MEPs or employees) with other institutions or citizens from the European Union. However, Halliday (1978) proposed another important function, i.e., the textual function, responsible for organizing the message in the text.

Within the SFG, the concept of function refers to the uses of language, as the use of language is determined by a specific contextual and cultural situation (the European Union context and cultural situation are shared by all the EU Members, although each EU Member has its own context and cultural situation). Language use would have been difficult to analyse in our corpus of three different languages. However, SFG methodology provides us with a set of functions common to all uses, because they are based on the context and their meaning is conveyed by grammatical structures. As Halliday and Hasan (1980: 32) affirm:

[...] functional variation not just as variation in the use of language, but rather as something which is built in, as the very foundation, to the organization of language itself, and particularly to the organization of the semantic system. In other words, function will be interpreted not as the use of language but as a fundamental property of language, embodied in the functional components of the semantic system.

In consequence, according to Halliday, the function in a clause is determined by the elements in the context or by the situation, i.e., the participants, what they are doing, their intentionality; when we talk about uses of the language we are not only interested in how language is used but in the intentionality, because language can vary depending on the speaker's purpose.

FIGURE 1

Language in social context (Martin 1992:4)

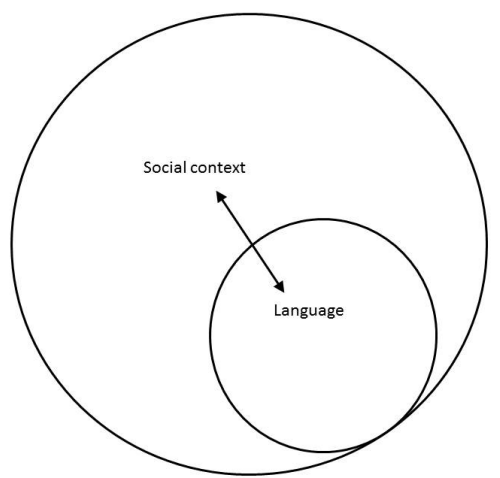

The SFG organizes language and social context through three meta-functions (Martin 1984) explained by Halliday (1978: 27-28) as:

The ideational function represents the speaker's meaning potential as an observer. It is the content function of language as 'about something.' [...] It expresses the phenomena 
of the environment: the things - creatures, objects, actions, events, qualities, states and relations - of the world and of our consciousness, including the phenomenon of language itself $[\ldots]$

The interpersonal component represents the speaker's meaning potential as an intruder. It is the participatory function of language, language as doing something [...]

The textual component represents the speaker's text-forming potential; it is that which makes the language relevant. This is the component which provides the texture; that which makes the difference between language that is suspended in vacuo and language that is operational in a context situation. [...] Hence the textual component has an enabling function with respect to the other two; it is only in combination with textual meanings that ideational and interpersonal meanings are actualized.

All of this can be projected in the context by three variables (Christi and Martin 1984 and Martin 1992):

- Field: the ongoing activity focused on EU policies, institutional practices and application of EU law.

- Tenor: the relationships between the participants, i.e., between MEPs, Parliament and Institutions, Parliament and Member States, Parliament and citizens.

- Mode: the way and discursive roles carried out during an activity.

Thus, we could say that each metafunction of language corresponds to a variable in the context.

\section{FIGURE 2}

\section{Diversification of language and social context (Martin 1992: 4)}

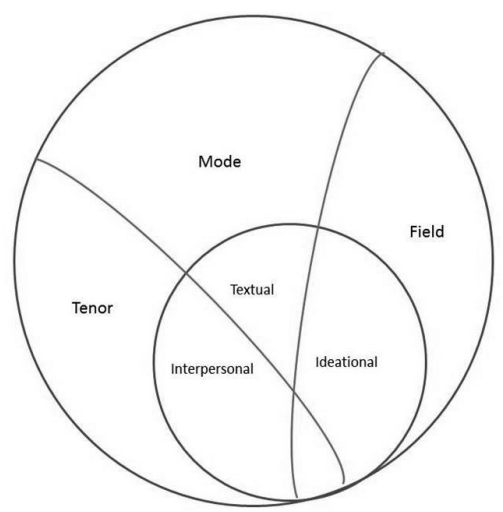

\subsubsection{The ideational function: transitivity}

As mentioned above, the ideational function is the representation of experience, i.e., our experience inside the world around us, and within us, the world of our imagination. That is, the representation of the world in its broadest sense, or, as Halliday (1974: 50) puts it, transitivity, understood as: "[...] the grammar of processes - of actions, mental processes, relations - and the participants in these processes, and the attendant circumstances."

Transitivity is the most important line of this research, because through it the ideational function of language is manifested in the structure of a clause. It is true 
that not all parliamentary bodies produce texts on the same topic, but all of them use these texts to evaluate certain issues or situations, whether they are reports, opinions or written questions. Such issues or situations are developed to talk to the world about the world. According to Downing (2006: 123):

The semantic schema for a situation, therefore, consists potentially of the following components:

- the process (a technical term for the action (e.g. hit, run), state (e.g. have) or change of state (e.g. melt, freeze) involved;

- the participant(s) involved in the process (basically, who or what is doing what to whom);

- the attributes ascribed to participants; and the circumstances attendant on the process, in terms of time, place, manner, and so on.

(Downing 2006: 123)

Thus, a process is part of the experiential meaning and the nucleus of a situation. For example, in the situation The Treaty of Lisbon brings the importance of a transparency to a new level by virtue of Article 10/TEU, Paragraph 3 the process is brings, which is the main verb; the same situation happens in the Spanish and French versions: in El Tratado de Lisboa eleva la transparencia a un nuevo nivel de importancia en virtud del artículo 10, apartado 3, del TUE the main verb is eleva and in Le traité de Lisbonne rehausse l'importance de la transparence avec l'article 10, paragraphe 3, du traité sur l'Union européenne the main process is rehausse.

Following the same line, Downing (2006: 123) states that there are three main types of processes:

- Material processes: processes that express an action that is taking place (to run, to eat, to give ...) or is happening (to fall, to collapse, etc.).

- Mental processes, or experiential or perception processes (to hear, to see, to feel, to know, etc.). These processes are divided into three groups: cognitive process as to know, to think, to believe, or perceptive verbs as to hear, to see, to feel or affective verbs as to love or to hate.

- Relational process as to be, to seem or to become.

And three secondary processes:

- Behavioural processes: they are processes standing between material and mental processes like breathing, coughing, smiling, dreaming, chatting, watching, etc.

- Verbal processes: These are processes of speaking like: asking, questioning, repeating, etc.

- Existential processes: those that indicate the existence of something: there is/there are.

Usually, the number and kind of participants is determined by the type of processes (Downing 2006: 126):

Traditionally, the term intransitive has been used to refer to verbs that express oneparticipant processes such as fall or non-participant processes such as rain, whose action does not refer to any Object. The term transitive has been used to refer to verbs and clauses in which process extends to one or more Objects.

However, it is important to clarify that the type of process determines the participants in the clause. The participants involved in each process are: 
1) Material process:

- Agent: the entity that develops or carries out the process

- Goal: the entity towards which a process is directed.

- Affected: the entity for whom/which something is done.

- Effected: the result of the action.

- Recipient: the entity, normally animated, to whom/which something is given, passed, sent...

- Beneficiary of the process

2) Mental process:

- Experiencer Agent: the entity that develops the process.

- Experiencer Recipient: the entity, normally animated, who feels the experience.

- Phenomenon: what is felt, thought or seen.

3) Relational process:

- Subject: Carrier: the entity who develops or does the process.

- Predicate: Attributive, circumstantial or possessive.

4) Behavioural process:

- Experiencer: the entity that displays the behaviour.

- Phenomenon: the result of the behaviour.

5) Verbal process:

- Sayer: the person who speaks

- Verbiage (reported statement (that clause), reported question, reported directive (to-infinitive clause)): the content of what is said.

6) Existential process: Existent.

TABLE 3

Table of processes and participants by Halliday (1985: 131)

\begin{tabular}{|l|l|l|}
\hline Process type & Category Meaning & Participants \\
\hline $\begin{array}{c}\text { Material: } \\
\text { action } \\
\text { event }\end{array}$ & $\begin{array}{c}\text { 'doing' } \\
\text { 'doing' } \\
\text { 'happening' }\end{array}$ & Actor, Goal \\
\hline Behavioral & 'behaving' & Behaver \\
\hline $\begin{array}{c}\text { Mental: } \\
\text { perception } \\
\text { affection } \\
\text { cognition }\end{array}$ & $\begin{array}{c}\text { 'sensing' } \\
\text { 'seeing' } \\
\text { 'feeling' } \\
\text { 'thinking' }\end{array}$ & Senser, Phenomenon \\
\hline Verbal & 'saying' & Sayer, Target \\
\hline $\begin{array}{c}\text { Relational: } \\
\text { attribution } \\
\text { identification }\end{array}$ & $\begin{array}{c}\text { 'being' } \\
\text { 'attributing' } \\
\text { 'identifying' }\end{array}$ & $\begin{array}{c}\text { Token, Value } \\
\text { Carrier, Attribute } \\
\text { Identified, Identifier }\end{array}$ \\
\hline Existential & 'existing' & Existent \\
\hline
\end{tabular}

\section{Results}

\subsection{The processes}

After analysing the texts according to the methodology proposed by the SFG, we found a high percentage of material processes, followed by experiential processes in EP technical texts.

Below, we present a paragraph in the three languages under study (English, Spanish and French) in which it is possible to appreciate the abundance of the material processes. The processes appear underlined and the type of process in brackets: 
(1) Following the stand off in the WTO between the United States of America (US) and the Union over imports of 'hormone treated (//material process//) beef,' an agreement has now been reached (//material process//) between them that will bring (//material process//) to an end this long lasting and damaging dispute.

This solution, negotiated ( $\operatorname{cog} M E N)$ by Catherine Ashton, then EU Trade Commissioner, and the US Government was signed (//material process//) on 13 May 2009. The deal foresees (//mental process//) a two-phase arrangement whereby the US progressively reduces (//material process//) the level of sanctions imposed (//material process//) on Union products, while the Union progressively increases (//material process//)_its tariffrate quota (TRQ) for hormone-free "High Quality" beef. The first phase of this agreement was established (//material process//) in Council Regulation (EC) No 617/2009 opening up (//material process//) an additional TRQ of 20,000 tonnes and in return the US removed $68 \%$ of their listed sanctions. It is (//relational process//) now time to approve (//material process//) the second phase of this agreement which must be implemented (//material process//) by 1st August 2012, according to the relevant Memoranda of Understanding. This second step entails (//relational process//) a complete removal of the US sanctions, in exchange for a further expansion of the Union TRQ by 25,000 tonnes for the US and 3,200 tonnes for Canada.

\section{Spanish:}

(2) Tras el estancamiento de las negociaciones en la OMC entre los Estados Unidos de América y la Unión sobre las importaciones de «vacuno tratado (//material process//) con hormonas", ambas partes acaban de llegar (//mental process//) a un acuerdo que pondrá fin (//material process//) a este prolongado y dañino litigio.

Esta solución, negociada (Cog MEN) por Catherine Ashton, entonces Comisaria de Comercio de la UE, y el Gobierno de los EE.UU., se firmó (//material process//) el 13 de mayo de 2009. Prevé (Cog MEN) un acuerdo en dos fases por el que EE.UU. reduce (//material process//) progresivamente el nivel de las sanciones impuestas (//material process//) a los productos de la Unión, mientras que la Unión aumenta (//material process//) progresivamente el contingente arancelario para la carne de vacuno de "calidad superior" no tratada con hormonas. La primera fase del acuerdo se estableció (//material process//) mediante el Reglamento (CE) no 617/2009 del Consejo, que abrió (//material process//) un contingente adicional de 20000 toneladas, mientras que, en contrapartida, EE.UU. retiró (//material process//) el 68\% de las sanciones reseñadas. Llega (//relational process//) ahora el momento de aprobar (//material process//) la segunda fase del acuerdo, que debe aplicarse (//material process//) antes del 1 de agosto de 2012 con arreglo al correspondiente Memorándum de entendimiento. Esta segunda fase supone (//relational process//) la retirada completa de las sanciones estadounidenses a cambio de una nueva ampliación del contingente arancelario de la Unión, en 25000 toneladas para EE.UU. y 3200 toneladas para Canadá.

French:

(3) Après une période de tensions, au sein de l'OMC, entre les États-Unis d'Amérique et l'Union au sujet des importations de viande de bouf aux hormones, les deux parties sont parvenues (//material process//) à un accord qui mettra fin (//material process//) à ce différend long et préjudiciable.

Cet accord, négocié (//mental process//) par Catherine Ashton, alors commissaire européenne en charge du commerce, et le gouvernement des États-Unis, a été signé (//material process//) le 13 mai 2009. Il prévoit (//mental process//) un arrangement en deux phases en vertu duquel les États-Unis réduisent (//material process//) progressivement le niveau des sanctions imposées (//material process//) sur les produits de l'Union tandis que 
l'Union accroît (//material process//) progressivement son contingent tarifaire (CT) pour la viande bovine de haute qualité exempte d'hormones. La première phase de cet accord a fait l'objet (//material process//) du règlement $d u$ Conseil (CE) $n^{\circ}$ 617/2009 portant ouverture (//material process//) d'un CT de 20000 tonnes alors que, pour leur part, les États-Unis retiraient (//material process//) 68\% des sanctions figurant sur leur liste. Il s'agit (//relational process//) à présent d'approuver (//material process//) la deuxième phase de cet accord qui, conformément aux protocoles d'entente pertinents, doit entrer en vigueur (//material process//) le ler août 20122. Cette deuxième phase comporte (//relational process//) la levée complète des sanctions américaines en échange d'un CT de l'Union de 25000 tonnes pour les États-Unis et de 3200 tonnes pour le Canada.

We appreciate that most of the processes are the same in the different languages under study. In The first phase of this agreement was established (MAT) in Council Regulation (EC) No 617/2009 [...] sentence, the main process is was established, a material process, so in Spanish and in French se estableció and a fait l'objet, respectively, both are material processes as well.

In the case of final reports the percentage of mental processes of perception is higher than that of cognitive mental processes. This increase is due to the employment of enacting clauses (Alcaraz 2008), i.e., a short phrase that introduces the main provisions of a law enacted by a legislature. It usually declares the source from which the law claims to derive its authority, as having regard, visto/a/s, $\underline{v u}$ :

(4) Having regard to Article 148(2) of the Treaty on the Functioning of the European Union, pursuant to which the Council consulted Parliament (C7 0410/2012).

Visto el artículo 148, apartado 2, del Tratado de Funcionamiento de la Unión Europea, conforme al cual ha sido consultado por el Consejo (C7-0410/2012).

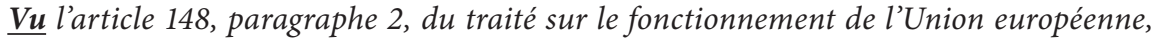
conformément auquel il a été consulté par le Conseil (C7-0410/2012).

In amendments, we found an increase of verbal processes in comparison with the rest of the texts and in reports as recalls, requires, call for and their equivalents recuerda, pide in Spanish and demande in French, in clauses such as shown below, in which a MEP calls for a change in a Resolution:

(5) Calls for the EU to negotiate a concrete roadmap for implementation with the Ukrainian authorities

Pide a la UE que negocie con las autoridades ucranianas una hoja de ruta concreta para su aplicación

Demande que l'Union négocie une feuille de route concrète à mettre en oeuvre en collaboration avec les autorités ukrainiennes.

In the following figures, we provide a comparison in numbers, after a qualitative (in order to classify the different processes in the studied texts) and quantitative analysis (in order to quantify the number and type of processes), among the three language versions of the four types of texts under study. 
FIGURE 3

General comparison of percentages in English

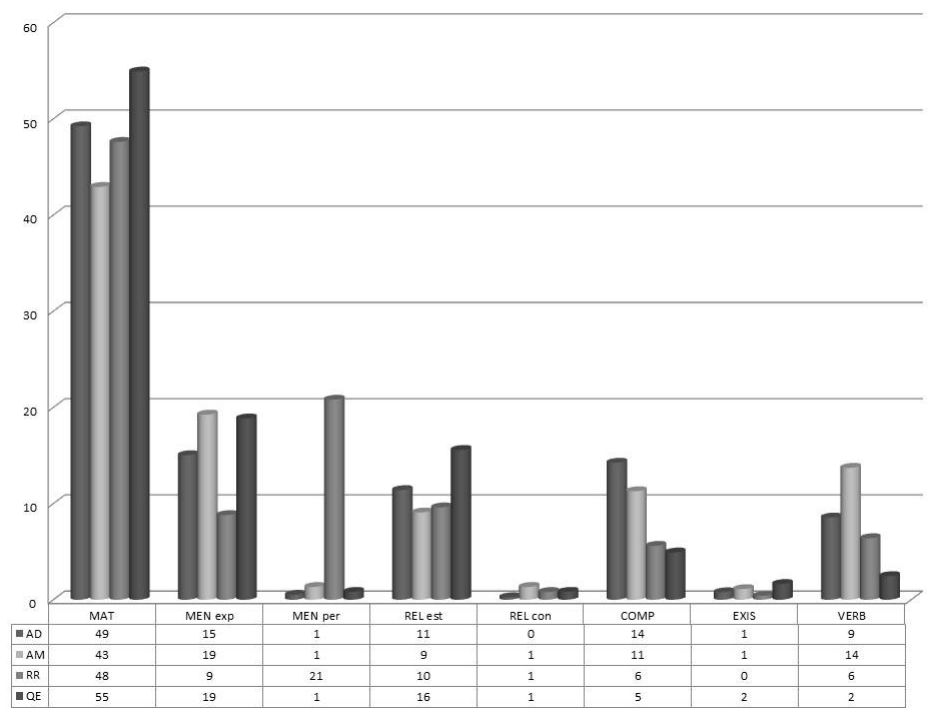

FIGURE 4

General comparison of percentages in Spanish

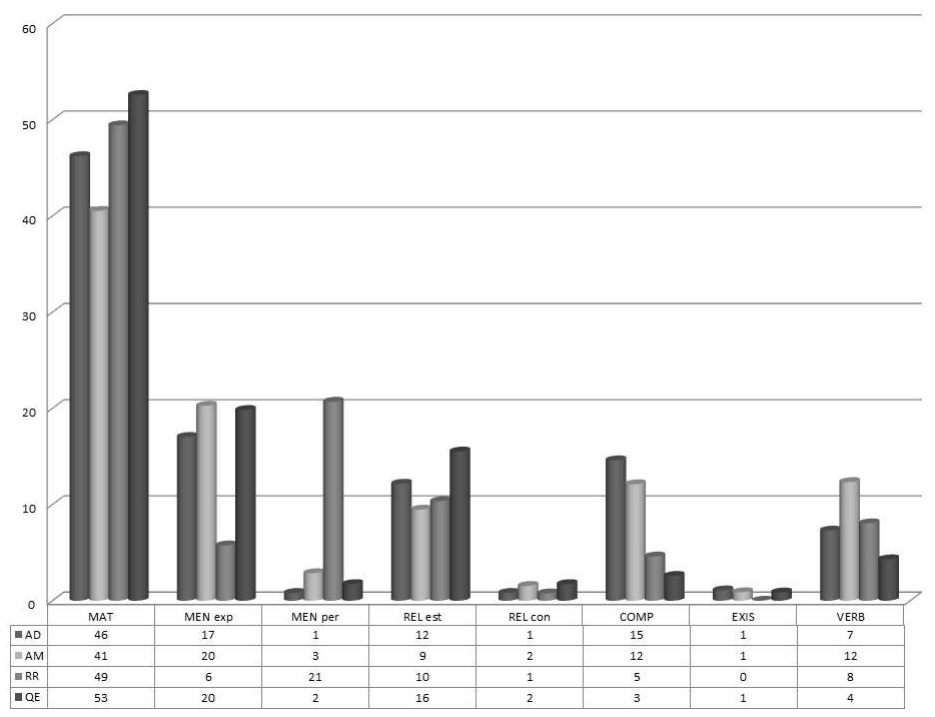


Figure 5

General comparison of percentages in French

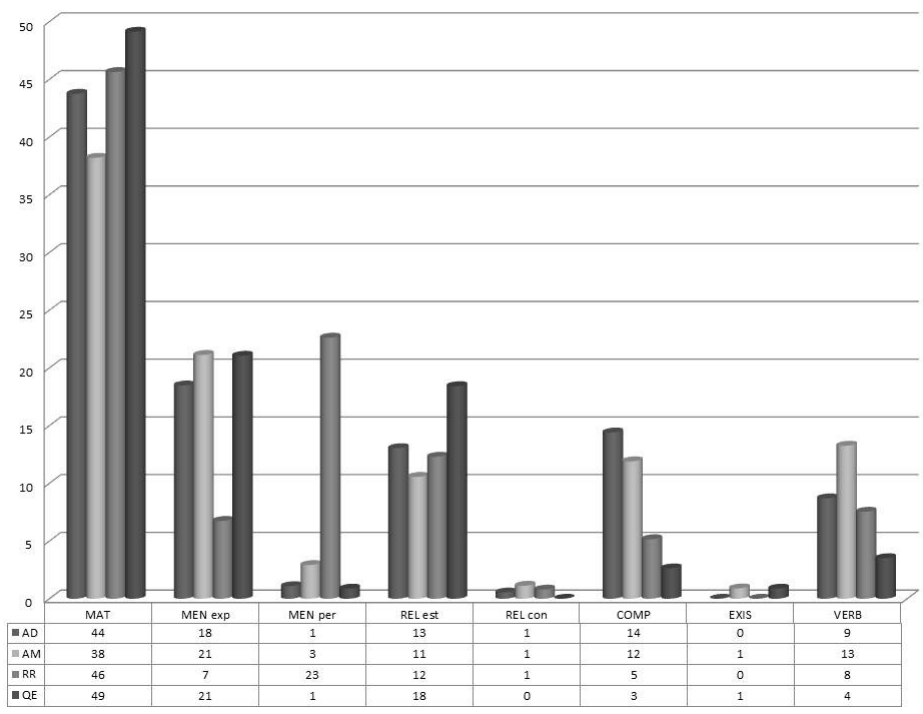

As shown in Figures 3, 4 and 5, material processes are the most used in the three languages.

Moreover, we would like to emphasise the use of some mental and verbal processes in the translated texts. After making a comparison of these processes in ParaConc Software and thanks to its parallel search function, we found that some mental processes have been translated into verbal processes and vice versa. In addition, in some texts the dominant function is the mental one and in other texts is the verbal one, becoming mixed nature processes. In the following fragment the function of the process demand is not only to request or to communicate something orally; in this case, the speaker is lobbying to fulfil what is dictated.

(6) [...] demands a complete end to the sale of arms and military equipment [...]

[...] exige que se acabe por completo con la venta de armas y equipos militares[...]

[...] exige qu'il soit mis fin définitivement à de telles ventes [...]

This feature is less common in material processes, but it can also be found (e.g., to state has as well a mixed nature - material/verbal - as it is in the following sentence "[...] by virtue of Article 10/TEU, Paragraph 3, which states that: 'Every citizen shall have the right'[...]" The TEU is not only telling (verbal process) somebody what to do, but is also legislating, and to legislate is with no doubt a material process.

However, some material processes, such as stressing, taking note and highlighting and their equivalents into Spanish and French, have a cognitive mental nature when material nature is its primary nature.

(7) In this regard, the rapporteur stresses that transparency is not only a matter of passive reactions by $E U$ institutions [...]

El ponente hace hincapié en que la transparencia no es sólo cuestión de reacciones pasivas por parte de las instituciones de la UE [...] 
La rapporteure pour avis souligne que la transparence ne passe pas seulement par des réactions passives de la part des institutions européennes [...]

In this example, the primary nature of the principal process is also material, understood as a process that expresses an action that is taking place. Nevertheless, its real function is a cognitive mental process, because the author is not only stressing, but also emphasising something, and that is the reason of using this verb. It is easier to understand this with the verb souligner in French, where there is nobody underlining the text, the author highlights an action in a figurative form because s/he wants to point it out.

The appendices 1 and 2 show the equivalences by frequency between processes in the languages studied.

\subsection{The participants}

As discussed in the methodology section, the processes used in the clauses condition participants However, in mixed processes, participants will depend on the dominant function of the process and not on its primary nature. In the following example, it is possible to appreciate that although highlight is a material process as explained above, in this clause it acts as a cognitive mental process, so your Rapporteur is an "experiencer agent" and some of the main benefits this agreement would bring to the Union is the "phenomenon," participants that usually act with mental processes. However, in this sentence we find a subordinate clause with the material process bring and the participants are an "agent," an "affected" as well as an "effected."

TABLE 4

Part of the analysis

\begin{tabular}{|l|l|l|l|l|l|}
\hline $\begin{array}{l}\text { Your } \\
\text { Rapporteur }\end{array}$ & $\begin{array}{l}\text { would like to } \\
\text { highlight }\end{array}$ & $\begin{array}{l}\text { some of the } \\
\text { main benefits }\end{array}$ & this agreement & would bring & to the Union. \\
\hline $\begin{array}{l}\text { Experiencer } \\
\text { Agent }\end{array}$ & $\begin{array}{l}\text { Mental } \\
\text { Process }\end{array}$ & Phenomenon & Agent & Mat Proc & Affected \\
\hline
\end{tabular}

Regarding the participants, we show only five illustrations with examples comparing the use of participants in the four types of texts in English that have been studied, as the percentages obtained in the analysis of the three languages are very similar.

In Figure 6, we can notice a high percentage of institutions performing the agent function, followed by legal acts and documents and then people. This is significant as a personification of institutions and documents is produced, human beings or animals normally carry out material processes.

(8) On 11 July 2006 the Council (//agent//) authorised (//material process//) the Commission to open negotiations with the Republic of Croatia

El 11 de julio, el Consejo (//agent//) autorizó (//material process//) a la Comisión a iniciar las negociaciones con la República de Croacia.

Le 11 juillet 2006, le Conseil (//agent//) a autorisé (//material process//) la Commission à ouvrir des négociations avec la République de Croatie. 
Figure 6

General comparison of the agent participant in the English version

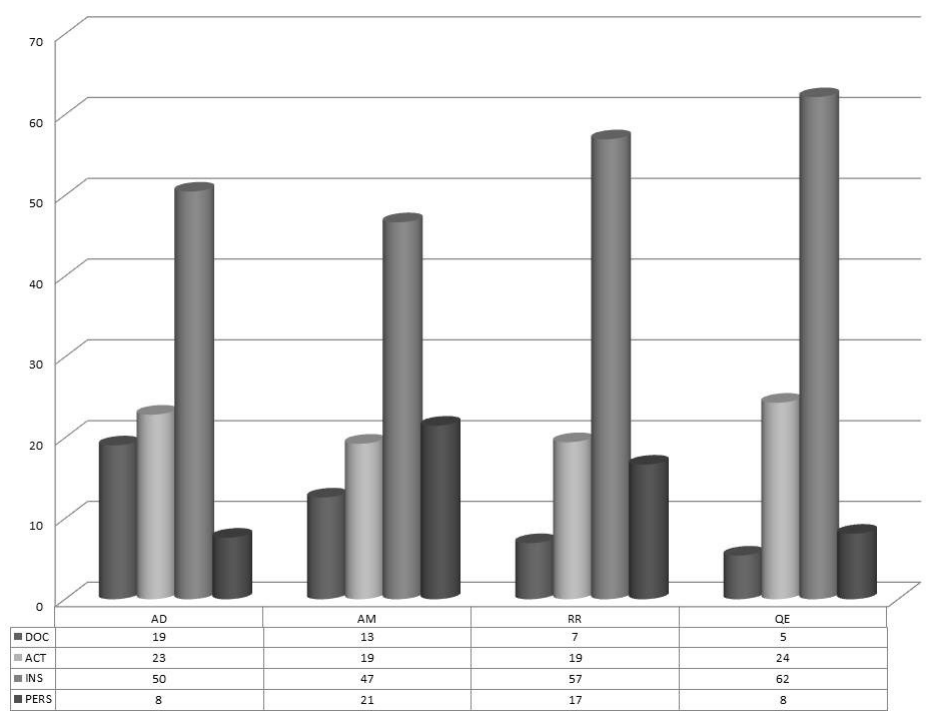

In this clause, the Council authorises the Commission to negotiate, the process negotiate is usually carried out by a human. We have found similar clauses with legal acts and documents in which articles and Regulations usually transfer, decide or perform actions normally taken by humans.

\section{FIGURE 7}

General comparison of the affected participant in the English version

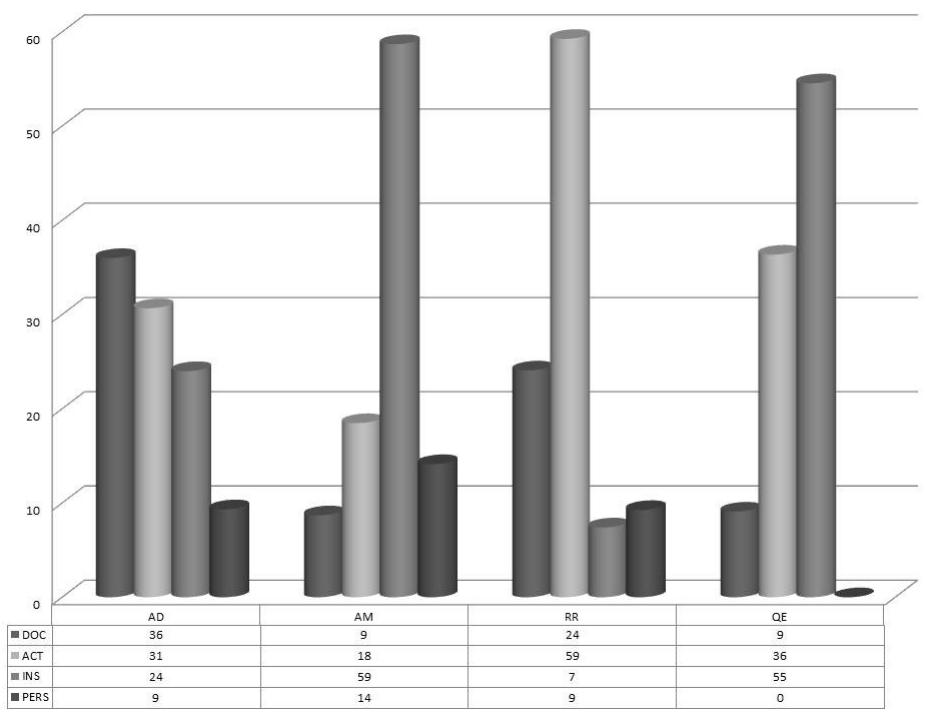


In the case of the affected function, there is no fixed rule. The only feature in common of the texts under survey is that people do not usually perform this function, but legal acts and documents and institutions do, as shown in the following clause, where the affected participant corresponds to rules and practices, because they are the participant amended: "Most of the EU institutions and bodies have already amended their own rules and practices."

FIGURE 8

General comparison of the recipient participant in the English version

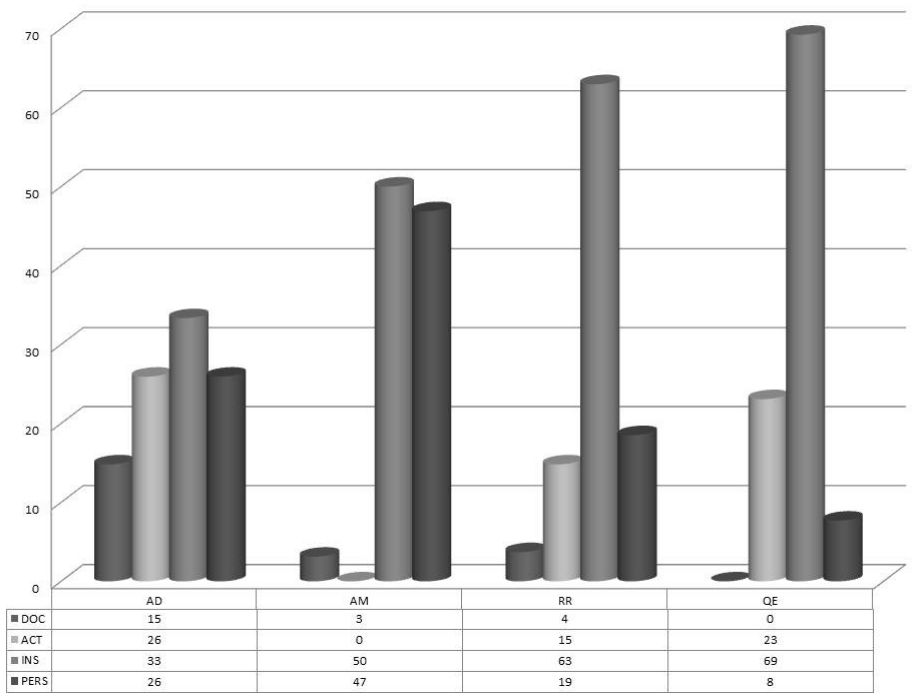

The recipient is the participant, normally animate, to whom/which something is given, sent, passed, etc. Figure 8 shows the high percentage of institutions performing the recipient role, as shown in the following sentence, the Office for Drugs is the recipient:

(9) Every therapeutic community (//agent//) has to provide (//material process//) data (//goal//) on treated patients (//affected//) to the Office for Drugs (//recipient//)

This is noteworthy from the point of view that the recipient is normally animate (a human or an animal), i.e., the process provide implies that something is given to somebody and not to something, but institutions here are treated as an entity, and this is the reason we have found here a personification. Compared with the functions studied above, it can be noticed that there is a clear decrease in the participation of legal acts and documents. However, we have found a significant increase of people participation as recipient in material processes in both opinions and amendments. 
Figure 9

General comparison of the beneficiary participant in the English version

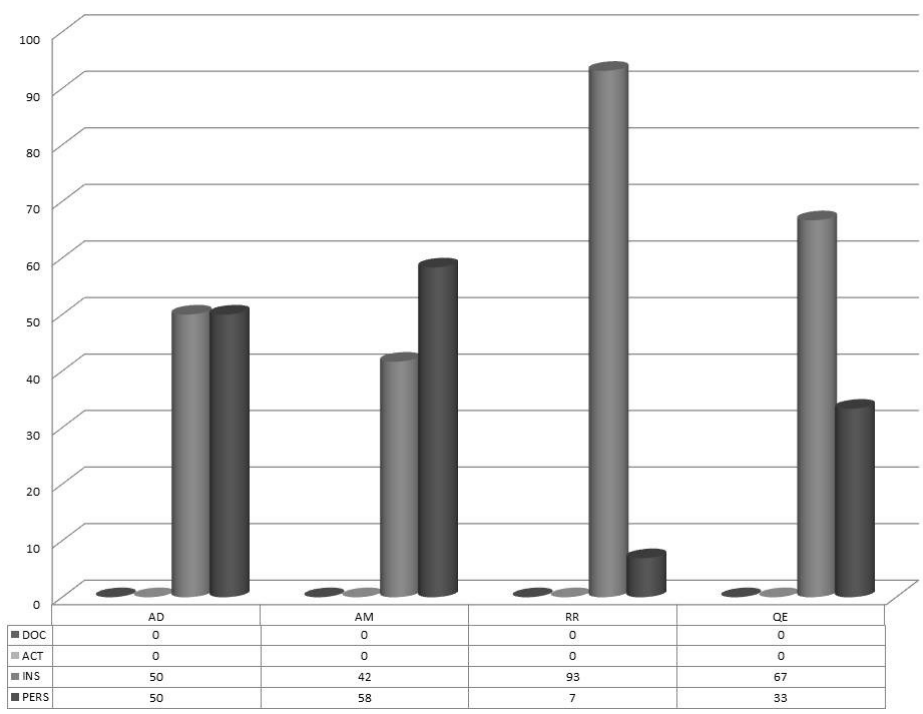

In Figure 9, the only two participants found are institutions and people, being people the most present in amendments and institutions in reports and written questions.

Finally, in Figure 10 we show a comparative percentage of the functions performed by the sayer participant in which, as expected, we can see a clear participation of people as sayer in written questions, since questions are usually posed by a person and sometimes by institutions acting as a person.

FIGURE 10

General comparison of the sayer participant in the English version

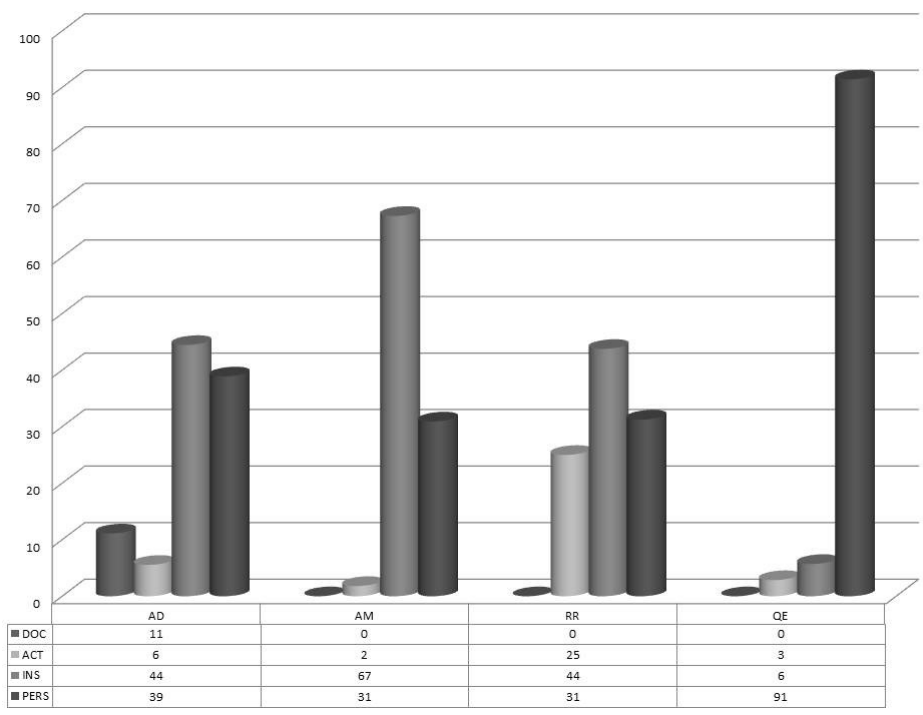




\section{Discussion}

Starting from our initial hypothesis that if "the EP technical texts have common linguistic features in their English, French and Spanish versions," as we have mentioned at the beginning of this article, we attempted to study and discuss EU texts concerned with political, legal, economic, technical and scientific areas, with the following main goals:

1. To identify the linguistic features characteristic of the technical texts produced by the European Parliament from the point of view of the ideational function.

2. To determine the most appropriate translation methods to be applied in this particular case.

In order to carry out the first goal and, therefore, to be able to determine the most appropriate translation methods, we have focused on the analysis of the ideational function, one of the three meta-functions (Halliday 1978; Martin 1984) proposed by Halliday's $(1978,2004)$ Systemic Functional Linguistics.

a) The ideational function, by which speakers interpret and organize their experience in the real world.

b) The interpersonal function, by which social relationships and communication roles are established and maintained.

c) The textual function, which allows speakers to create appropriate texts, the main unit of meaning transmission.

All these meta-functions are projected in context through three variables:

- Field: ongoing activity focused on institutional practices, EU policies and implementation of European law.

- Tenor: the relationships among participants, including MEPs, the European Parliament and the rest of institutions, the EP and Member States, EP and citizens.

- Mode: the way and the discursive roles played in one activity. The texts studied and how and why they have been created.

In accordance with the analysis proposed our main conclusions are the following:

Firstly, these texts are characterised by a predominance of material processes, in particular, actions linked to the legal, administrative and economic world: adopt, approve, modify, create, transmit, publish, establish, sign, etc., with their respective equivalents in Spanish and French. To a lesser extent, there are mental processes of cognition and verbal processes in the three analysed versions.

There are certain processes - material, mental (cognition) and verbal ones - that could have a mixed nature, as we have observed that equivalents are exchanged with each other in the different linguistic versions studied. This is the case of highlight, which in its primary nature is a material process, but in the studied texts is a cognitive mental process, as the 'subject' wishes to give importance to something, and not to actually underline a text. This aspect is significant, as the processes determine the participants, and in these cases, although the processes in their primary nature do a function, in these contexts they do another, so that the participants will be those that correspond to the function in the context.

In the final reports there are a high percentage of mental processes of perception; these processes appear in a non-personal form of the verb, more specifically in the past participle, and correspond in most cases to enacting acts as: 
(10) Having regard to Directive 2010/76/EU of the European Parliament and of the Council of 24 November 2010 amending Directives 2006/48/EC and2006/49/EC as regards capital requirements for the trading book and for re-securitisations, and the supervisory review of remuneration policies.

With regard to the participants (agent, affected, recipient, beneficiary and sayer), it must be noted that, in the corpus under study, most of them are institutions and acts/documents, when these participants usually are animated (human beings or animals). This way, the addresser looks for a personification of the text, gives it legitimacy and shifts the responsibility of the process to an institution or to a legislative act or document.

(11) The European Parliament sends a very important signal to the US [...]

In this sentence the European Parliament carries out an action usually done by human beings, giving legitimacy to the process and to the institution.

Secondly, we consider that the knowledge of these features could be useful for EU translators and can be used in the training of future translators as a guide in the translation process. As the knowledge of the features of texts is essential to translate specialised texts, in the case of new EU translators, these features could be taught by specific manuals created from studies like the present one or by doing specific seminars about the linguistic characteristics of EU texts and possible strategies of translation. Regarding the University environment, we suggest the creation of specific courses about institutional translation where the characteristics of these texts may be taught, either through manuals previously created on the features of the institutional texts and translation strategies, or the learning of these strategies through text analysis.

We should finally add that our research has a wider scope, namely, that of projecting the possible lines of future research. As we proposed before, it could be possible, by conducting a previous study of the rest of the meta-functions, to create a manual about the linguistic characteristics of EU texts with academic purposes.

Thirdly, and with regard to the second objective of this work, we contemplate some of the features proposed by the "Theory of Scope" of Vermeer later retaken by Nord (2009). We consider that these features must be present in the translation strategy of technical and administrative communication texts, although, due to the legal nature of the EU, there are certain nuances that should be taken into account:

a. Intention and function must be the same.

b. Text and coherence: we take the source text (ST) as an offer of information from which the receiver selects items of her/his interest. Taking into account that the translator is, at the same time, recipient and speaker, we have to consider that, owing to the principle of equality and legal equivalence in the case of EU texts, the translator-recipient cannot select items that s/he considers important but s/he must select all, because s/he could break the principle of equality and legal equivalence.

c. Culture and cultural issues: within the EU there is a common culture and a different one for each Member State. In the texts studied, the main recipient of the source text is the same as the target one (institutions, parliamentary committees, EU deputies). This way the source culture is essentially the same as the target culture. In other texts, for example, the regulatory ones, we must bear in mind that the EU is a supranational organization, i.e., Member States have to adapt their legal systems in order to transpose EU laws, so the original culture prevails. However, we must consider 
the terminology of this European culture, Eurospeak, in which the translators have to seek translation strategies to transfer these culturemes to the target culture.

d. Adequacy and equivalence: the texts of our study are a particular case and the concept of equivalence must always be present in them.

e. Functionalism and loyalty: a good translation is that which arises from the compromise between the Scope and loyalty to all participants in the communication process (López Rodríguez, 2001).

Furthermore, we propose the function-based translation as the translation strategy, although we believe that translators will have to adopt mixed strategies of translation. We believe that EU translation should have the same goal of documentary translation, where the speaker and the recipient of an original culture communicate to each other through a text under the same conditions of the same culture. In this case, the culture of the target recipient is the same as the origin speaker/recipient. All this with the particular condition that the target recipient must not perceive TT as a translation, according to the principle of equality, a feature of instrumental translation. In addition, the same function must be transmitted, as in equifunctional translation, where the source's text function remains the same in the target text, maintaining the "legal equivalence."

Then again, as we have pointed out, technical texts constitute the majority of the translation volume in the European Parliament, thus providing the basis for the fulfilment of legislative texts that later will be transposed into national laws. As we have confirmed in this piece of research, most studies of EU texts have been focused on legislative texts, not giving the relevance deserved to technical texts and other types of EU texts. We consider that it is very important to continue identifying the characteristics of the rest of the technical and administrative texts, because their study could be useful for EP translators and also for the rest of the translators in the EU institutions.

The methodology proposed by SFL (Halliday 1978, 2004) allows us to perform a qualitative analysis of the texts in order to find their internal characteristics, which could also be applied to the rest of the texts and technical administrative communication from a linguistic point of view. Surely, the Corpus Linguistics methodology should allow us to carry out a representative analysis, from the standpoint of Translation Studies, of the whole texts produced by EP, so that we could provide standardized guidelines for multilingual translation. Moreover, and for the same reason, we also believe that the study of EU informative texts, not traditionally considered as institutional texts, is essential to achieve the same goals.

From a linguistic point of view, it would be interesting to conduct a study on whether there is a neutralization of languages in European institutions, firstly, due to the already well-known legal equivalence and, secondly, due to the social and multicultural context existing in the European institutions, where texts (oral and written) are produced by non-native speakers. It is well known that non-native speakers usually simplify the second language they speak and we wonder if this simplification could produce a neutralization and degradation of the languages in international organizations. We consider that some comparative studies in this area could be done by means of the study of oral texts in the UK Parliament and EU Parliament or of written texts from national institutions and international institutions. We propose to use the Corpus Linguistics Methodology in order to research the linguistic 
differences between the use of the same language spoken by native and non-native speakers with a good command of the language. Furthermore, we wonder as well if there is a will to make languages more universal in order to facilitate communication.

Finally, we consider it imperative to tackle the potential educational use of these results. In this sense, we start from the basis that institutional translation should be part of the comprehensive training of all future translators, as we pointed out before. We consider that this path could start by doing seminars in this area or by including specific subjects in Master's Degrees or Ph.D. programs. In particular, our results clearly show how essential it is for future translators to have knowledge about institutional translation.

\section{NOTES}

1. For more information: European Parliament (2015). Register of documents of European Parliament. $<$ http://www.europarl.europa.eu/RegistreWeb/search/simpleSearchHome.htm?language=EN> [Accessed 3 Mar. 2015]

2. The number of documents makes reference to translated documents or to documents that could be translated.

\section{REFERENCES}

BIBER, D. (1993): Representativeness in Corpus Design. Literary and Linguistic Computing, 8(4):243-257. <http://llc.oupjournals.org/cgi/doi/10.1093/llc/8.4.243> [Accessed 3 Mar. 2015].

Biber, D., Conrad, S. and Reppen, R. (1998): Corpus Linguistics: Investigating Language Structure and Use. Cambridge: Cambridge University Press.

Bowker, L., and Pearson, J. (2002): Working with Specialized Language. Abingdon, UK: Taylor \& Francis.

CATford, J.C. (1977): Una teoría lingüística de la traducción. Ensayo de Lingüística Aplicada. Caracas: Universidad de Venezuela.

Downing, A. \& Locke, P. (2006). English Grammar. A University Course. 2a Ed. Abingdon: Routledge.

European Parliament (2015). Register of documents of European Parliament. $<$ http://www.europarl.europa.eu/RegistreWeb/search/simpleSearchHome.htm?language=EN> [Accessed 3 Mar. 2015]

Garrido and Navarrete, M.A. (2004): Traducción institucional: el caso de la Unión Europea. In: S., Cruces Colado and A., Luna Alonso, eds, La traducción en el ámbito institucional: autonómico, estatal y europeo. Vigo: Universidade de Vigo, 151-186.

Gómez GonzÁLez-Jover, A. (2002): La equivalencia como cuestión central de la traducción en las instituciones de la Unión Europea. In: Actas del I Congreso Internacional sobre El español, lengua de traducción. Almagro. 2002.

$<$ http://www.esletra.org/Almagro/html/gomez_gonzalez_doc_es.htm> [Accessed 3 Mar. 2015]

Halliday, M.A.K. (1985 [1989]): An Introduction to Functional Grammar. London: Arnold.

Halliday, M.A.K. \& Hasan, R. (1976): Cohesion in English. London: Longman.

Halliday, M.A.K. \& Hasan, R. (1989, [1985, 1980]): Language, contexts and text: aspects of language in a social-semiotic perspective. Oxford: Oxford University Press.

Halliday, M.A.K and Matthiessen, C.M.I.M. (2004): An Introduction to Functional Grammar. 3rd Edition. London: Hodder Arnold.

Hatim, B. and Mason, I. (1995): Teoría de la traducción. Una aproximación al discurso. Barcelona: Ariel.

Koskinen, K. 2001. How to research EU Translation. Perspectives-Studies in Translatology, volumen 9:4, 293-300.

Martin, J. R. (1984): Language, Register and Genre. In: F., Christie, ed, Children Writing: Reader. Geelong, Vic: Deakin University Press, 21-29. 
Martin, J.R. (1992): English text: System and Structure. Amsterdam: John Benjamins.

Neubert, A. and Shreve, G., (1992): Translation as text. Kent, Ohio: Kent State University.

Nord, C. (1997): A functional typology of translations. In:A. Trosborg, ed, Text typology and translation. Amsterdam: J. Bejanmins.

Pérez Hernández, M.C., (2002): Explotación de los córpora textuales informatizados para la creación de bases de datos terminológicas basadas en el conocimiento. Estudios de Lingüística del Español (ELiEs), 18. <http://elies.rediris.es/elies18/index.html> [Accessed 15 Mar. 2015].

Pyм, A. (2000): The European Union and its future languages. Questions for language policies and translation theories. Across languages and cultures, 1(1), 1-17.

Reiss, K and Vermeer, H. (1996): Fundamentos para una teoría funcional de la traducción. Madrid: Ediciones Akal.

Sinclair, J. (1991): Corpus, Concordance, Collocation. Oxford: Oxford University Press.

SinClair, J. (1996): Preliminary recommendations on corpus typology. EAGLES Document TCWG-CTYP/P. <http://www. ilc. pi. cnr. it/EAGLES/corpustyp/corpustyp. html> [Accessed 15 Mar. 2015].

Toury, G. (1995): Descriptive Translation Studies and beyond. Amsterdam-Philadelphia: John Benjamins.

Veroz, M.A. (2010): Traducción institucional: un caso práctico en el Parlamento Europeo. In: C., Balbuena, M. Álvarez and R. López-Campos. Traducción y modernidad: textos científicos, jurídicos, económicos y audiovisuales. 135-151. Córdoba: Servicio de Publicaciones de la Universidad de Córdoba.

Veroz, M.A. (2010): Aproximación a los textos técnicos del Parlamento Europeo: los informes. Híkma, 9, 259-278.

Veroz, M.A. (2012): La traducción en la UE. Estudio sistémico funcional de un corpus sobre las opiniones parlamentarias. In: V., López Folgado and M.M. Rivas Carmona. Essays on Translation /Ensayos de traducción. Hamburg: Verlag Dr. Kovač, 247-269.

Veroz, M.A. (2013). The translation of grammatical metaphor in Europarlamentary opinions. In: M.M. Rivas Carmona and C. Balbuena Torezano, eds, Cultural Aspects of Translation/Ensayos de traducción. Tübingen: Narr Verlag.

Veroz, M.A. (2013). Traducción en la UE: estudio sistémico funcional de un corpus sobre la PAC. Skopos. Revista Internacional de Traducción e Interpretación. 2 (2), 187-210.

WAGNeR, E., BENCH, S. and MARTÍNez, J. (2002): Translating for the European Union Institution. Manchester: St. Jerome.

\section{APPENDICES}

Appendix 1

Process equivalence English $>$ Spanish

\begin{tabular}{|c|c|c|c|c|c|}
\hline English & Frec. & Process & Spanish & Frec & Process \\
\hline To be convinced & 1 & Cog MEN & Estar convencido & 1 & Cog MEN \\
\hline To be of the view & 1 & Cog MEN & Estimar & 1 & Cog MEN \\
\hline To restate & 1 & VERB & Pedir & 1 & VERB \\
\hline To invite & 1 & VERB & Recordar & 1 & VERB \\
\hline To state & 2 & $\begin{array}{c}\text { VERB } \\
\text { MAT }\end{array}$ & Establecer & 2 & $\begin{array}{c}\text { VERB } \\
\text { MAT }\end{array}$ \\
\hline \multirow{2}{*}{ To conclude } & 2 & Cog MEN & Considerar & 1 & Cog MEN \\
\cline { 4 - 6 } & 2 & VERB & Llegar a & 1 & Cog MEN \\
\hline To request & 2 & \multirow{2}{*}{ VERB } & Proponer & 1 & VERB \\
\cline { 4 - 6 } To suggest & \multirow{2}{*}{2} & Sugerir & 1 & VERB \\
\hline
\end{tabular}




\begin{tabular}{|c|c|c|c|c|c|}
\hline English & Frec. & Process & Spanish & Frec & Process \\
\hline To insist & 2 & VERB & Reiterar & 2 & VERB \\
\hline \multirow{2}{*}{ To agree } & \multirow{2}{*}{2} & \multirow{2}{*}{ Cog MEN } & Considerar & 1 & Cog MEN \\
\hline & & & Reconocer & 1 & Cog MEN \\
\hline To recognise & 3 & Cog MEN & Reconocer & 3 & Cog MEN \\
\hline To demand & 3 & $\begin{array}{l}\text { VERB } \\
\text { Cog MEN }\end{array}$ & Exigir & 2 & $\begin{array}{c}\text { VERB } \\
\text { Cog MEN }\end{array}$ \\
\hline To recall & 4 & VERB & Recordar & 4 & VERB \\
\hline To underline & 4 & Cog MEN & Subrayar & 4 & Cog MEN \\
\hline \multirow[t]{2}{*}{ To point out } & \multirow[t]{2}{*}{4} & \multirow[t]{2}{*}{ Cog MEN } & Señalar & 3 & $\begin{array}{l}\text { Cog MEN } \\
\text { VERB }\end{array}$ \\
\hline & & & Considerar & 1 & Cog MEN \\
\hline \multirow{2}{*}{ To be aware } & \multirow{2}{*}{4} & \multirow{2}{*}{ Cog MEN } & Ser consciente & 1 & Cog MEN \\
\hline & & & Tener conocimiento & 1 & Cog MEN \\
\hline To take into account & 8 & Cog MEN & Tener en cuenta & 2 & Cog MEN \\
\hline \multirow{2}{*}{ To take the view } & \multirow{2}{*}{8} & \multirow{2}{*}{ Cog MEN } & Considerar & 7 & Cog MEN \\
\hline & & & Estimar & 1 & Cog MEN \\
\hline \multirow{5}{*}{ To emphasise } & \multirow{5}{*}{9} & \multirow{5}{*}{ Cog MEN } & Destacar & 4 & Cog MEN \\
\hline & & & Insistir & 2 & Cog MEN \\
\hline & & & Opina & 1 & Cog MEN \\
\hline & & & Poner de relieve & 1 & Cog MEN \\
\hline & & & Subrayar & 1 & Cog MEN \\
\hline To support & 9 & Cog MEN & Apoyar & 2 & Cog MEN \\
\hline To propose & 11 & VERB & Proponer & 6 & VERB \\
\hline \multirow{3}{*}{ To highlight } & \multirow{3}{*}{11} & \multirow{3}{*}{ Cog MEN } & Señalar & 9 & $\begin{array}{c}\text { Cog MEN } \\
\text { MAT }\end{array}$ \\
\hline & & & Destacar & 1 & Cog MEN \\
\hline & & & $\begin{array}{c}\text { Expresa su particular } \\
\text { preocupación }\end{array}$ & 1 & VERB \\
\hline \multirow{4}{*}{ To stress } & \multirow{4}{*}{12} & \multirow{4}{*}{ Cog MEN } & Subrayar & 6 & Cog MEN \\
\hline & & & Destacar & 2 & Cog MEN \\
\hline & & & Hacer hincapié & 2 & Cog MEN \\
\hline & & & Insistir & 1 & Cog MEN \\
\hline \multirow{2}{*}{ To call on } & \multirow{2}{*}{12} & VERB & Pedir & 12 & VERB \\
\hline & & VEKD & Instar & 1 & VERB \\
\hline To call for & 12 & VERB & Pedir & 12 & VERB \\
\hline & & & Exigir & 7 & $\begin{array}{c}\text { VERB } \\
\text { Cog MEN }\end{array}$ \\
\hline & & & Obligar & 3 & $\begin{array}{c}\text { VERB } \\
\text { Cog MEN }\end{array}$ \\
\hline To require & 17 & VERB & Pedir & 2 & VERB \\
\hline & & & Requerir & 2 & $\begin{array}{c}\text { VERB } \\
\text { Cog MEN }\end{array}$ \\
\hline & & & Precisar & 1 & $\begin{array}{c}\text { VERB } \\
\text { Cog MEN }\end{array}$ \\
\hline & & & Considerar & 14 & Cog MEN \\
\hline To consider & 19 & Cog MEN & Estimar & 1 & Cog MEN \\
\hline & & & Opinar & 1 & $\begin{array}{c}\text { VERB } \\
\text { Cog MEN }\end{array}$ \\
\hline & & & Considerar & 14 & Cog MEN \\
\hline To believe & 19 & Cog MEN & Opinar & 3 & $\begin{array}{c}\text { VERB } \\
\text { Cog MEN }\end{array}$ \\
\hline & & & Creer & 2 & Cog MEN \\
\hline & & & Observar & 11 & Per MEN \\
\hline To note & 19 & Per MEN & Señalar & 4 & $\begin{array}{c}\text { Cog MEN } \\
\text { MAT }\end{array}$ \\
\hline & & & Constatar & 2 & Cog MEN \\
\hline
\end{tabular}




\section{Appendix 2}

\section{Process equivalence English $>$ French}

\begin{tabular}{|c|c|c|c|c|c|}
\hline English & Frec & Process & French & Frec & Process \\
\hline To be convinced & 1 & Cog MEN & Être convaincu & 1 & Cog MEN \\
\hline To be of the view & 1 & Cog MEN & Estimer & 1 & Cog MEN \\
\hline To restate & 1 & VERB & Rappeler & 1 & VERB \\
\hline To invite & 1 & VERB & Inviter & 1 & VERB \\
\hline To state & 2 & $\begin{array}{l}\text { VERB } \\
\text { MAT }\end{array}$ & Disposer & 2 & $\begin{array}{l}\text { VERB } \\
\text { MAT }\end{array}$ \\
\hline \multirow[b]{2}{*}{ To conclude } & \multirow{2}{*}{2} & \multirow{2}{*}{ Cog MEN } & Aboutir & 1 & Cog MEN \\
\hline & & & Conclure & 1 & Cog MEN \\
\hline To request & 2 & VERB & Demander & 1 & VERB \\
\hline To insist & 2 & $\begin{array}{c}\text { VERB } \\
\text { Cog MEN }\end{array}$ & Insister & 1 & $\begin{array}{c}\text { VERB } \\
\text { Cog MEN }\end{array}$ \\
\hline \multirow{2}{*}{ To agree } & \multirow{2}{*}{2} & \multirow{2}{*}{ Cog MEN } & Convenir & 1 & Cog MEN \\
\hline & & & Estimer & 1 & Cog MEN \\
\hline To recognise & 3 & Cog MEN & Reconnaître & 3 & Cog MEN \\
\hline \multirow{2}{*}{ To demand } & \multirow[t]{2}{*}{3} & \multirow{2}{*}{$\begin{array}{l}\text { VERB } \\
\text { Cog MEN }\end{array}$} & Exiger & 1 & $\begin{array}{c}\text { VERB } \\
\text { Cog MEN }\end{array}$ \\
\hline & & & Réclamer & 1 & VERB \\
\hline To recall & 4 & VERB & Se rappeler & 4 & $\begin{array}{c}\text { VERB } \\
\text { Cog MEN }\end{array}$ \\
\hline To underline & 4 & Cog MEN & Souligner & 4 & Cog MEN \\
\hline \multirow{3}{*}{ To point out } & \multirow{3}{*}{4} & \multirow{3}{*}{ Cog MEN } & Souligner & 2 & Cog MEN \\
\hline & & & Considérer & 1 & Cog MEN \\
\hline & & & Faire remarquer & 1 & Cog MEN \\
\hline \multirow{3}{*}{ To be aware } & \multirow{3}{*}{4} & \multirow{3}{*}{ Cog MEN } & Avoir connaissance & 1 & Cog MEN \\
\hline & & & Être au fait de & 1 & Cog MEN \\
\hline & & & Être conscient & 1 & Cog MEN \\
\hline \multirow{2}{*}{ To take into account } & \multirow{2}{*}{8} & \multirow{2}{*}{ Cog MEN } & Souligner & 3 & Cog MEN \\
\hline & & & Tenir compte & 3 & Cog MEN \\
\hline \multirow[b]{2}{*}{ To take the view } & \multirow[b]{2}{*}{8} & \multirow[b]{2}{*}{ Cog MEN } & Estimer & 6 & Cog MEN \\
\hline & & & Rappeller & 1 & $\begin{array}{c}\text { VERB } \\
\text { Cog MEN }\end{array}$ \\
\hline To emphasise & 9 & Cog MEN & Souligner & 6 & Cog MEN \\
\hline \multirow{5}{*}{ To support } & \multirow{5}{*}{9} & \multirow{5}{*}{ Cog MEN } & Soutenir & 4 & Cog MEN \\
\hline & & & Appuyer & 1 & Cog MEN \\
\hline & & & Être favorable & 1 & Cog MEN \\
\hline & & & Favoriser & 1 & Cog MEN \\
\hline & & & Veiller & 1 & Cog MEN \\
\hline To propose & 11 & VERB & Proposer & 13 & VERB \\
\hline & & & Marquer & 9 & MAT \\
\hline To highlight & 11 & Cog MEN & $\begin{array}{l}\text { Exprimer en particulier } \\
\text { son inquiétude }\end{array}$ & 1 & VERB \\
\hline & & & Souligner & 1 & Cog MEN \\
\hline & & & Souligner & 5 & Cog MEN \\
\hline To stress & 12 & Cog MEN & Insister & 1 & $\begin{array}{l}\text { VERB } \\
\text { Cog MEN }\end{array}$ \\
\hline Th callon & 12 & VFRB & Inviter & 9 & VERB \\
\hline 10 call on & 12 & $V E R B$ & Demander & 3 & VERB \\
\hline & & & Demander & 6 & VERB \\
\hline & & & Appeler & 1 & VERB \\
\hline To call for & 12 & VERB & Réclamer & 1 & VERB \\
\hline & & & Souhaiter & 1 & Cog MEN \\
\hline
\end{tabular}


44 MetA, LXII, 1, 2017

\begin{tabular}{|c|c|c|c|c|c|}
\hline English & Frec & Process & French & Frec & Process \\
\hline \multirow{6}{*}{ To require } & \multirow{6}{*}{17} & \multirow{6}{*}{ VERB } & Nécessiter & 2 & Cog MEN \\
\hline & & & Demander & 2 & VERB \\
\hline & & & Constater & 1 & VERB \\
\hline & & & Faire observer & 1 & Per MEN \\
\hline & & & Requérir & & Cog MEN \\
\hline & & & Supposer & 1 & Cog MEN \\
\hline \multirow{3}{*}{ To consider } & \multirow{3}{*}{19} & \multirow{3}{*}{ Cog MEN } & Estimer & 12 & Cog MEN \\
\hline & & & Considérer & 3 & Cog MEN \\
\hline & & & Envisager & 1 & Per MEN \\
\hline \multirow{2}{*}{ To believe } & \multirow{2}{*}{19} & \multirow{2}{*}{ Cog MEN } & Estimer & 10 & Cog MEN \\
\hline & & & Être d'avis & 3 & Cog MEN \\
\hline \multirow{4}{*}{ To note } & \multirow{4}{*}{19} & \multirow{4}{*}{ Per MEN } & Noter & 7 & $\begin{array}{c}\text { Cog MEN } \\
\text { MAT }\end{array}$ \\
\hline & & & Constater & 4 & Cog MEN \\
\hline & & & Observer & 3 & Per MEN \\
\hline & & & Faire observer & 4 & Per MEN \\
\hline
\end{tabular}

